\title{
The Hidden Factor of Female Offending - Gender
}

\author{
Ranaweera K.G.N.U. \\ University of Sri Jayewardenepura, Sri Lanka \\ Corresponding author: ranaweera@sjp.ac.lk
}

Received: 13-05-2020

Revised: $28-07-2020$

Accepted: 29-09-2020

\begin{abstract}
The social concept of gender emphasizes the bond between society and people. Gender is not determined through the sexual characteristics of either women or men but constructed socially. Gender role is a social position that includes a variety of actions and attitudes that are usually considered acceptable, appropriate, or desirable for people based on their personal or biological sex. This research was based on "gender role and crime", and the main objective was to examine the impact of gender role towards the female offending in Sri Lankan context. A simple randoms ample of 60 convicted female prisoners from Welikada prison in Sri Lanka was selected as the sample and data were gathered using semi-structured interviews. Questions were focused on the crime committed, direct reason for committing, civil status and socio-economic background of the offenders. All 60 offenders could be categorized into five groups based on the "type of crime committed". Majority of the offenders were accused of "Drug possession and trafficking", and it holds 55\% from the whole. Prostitution (28\%), abortion (8.3\%), homicide (3.3\%) and financial fraud $(5 \%)$ were recognized as the other crimes committed. Economic status, addiction, social labelling, social indignity, motivation, and protection were identified as primary reasons for offending. "Gender role" has been played a particular part in female offender's life which is hidden from direct reasons. Female gender role is created an early civilization based on the household and childcare. Nevertheless, with the intangible change of society has disorganized the female gender role. Male gender role existed with the dominance of the household with minimal change. Female gender role became complicated within the limitations of traditional duties. Child socialization upgraded to structured education alone with money based basic needs. Females entered to all professionals expanding duties hold, while maintaining the responsibilities of traditional gender role. Although it showed an increment of education of females, it has supported to "fraud" indirectly. As major duties of female gender role created with biological features of the female body like accouchement, female body base hiding and escaping methods, vulnerability as rape and social labelling of indignity were unchanged. The research revealed female offending is a normal response by normal females towards abnormal gender conditions of the society. To address this social dilemma, gender role should be flexible; responsibilities should be taken by the family as an institution while mutual accountabilities are transferred for individuals.
\end{abstract}

Keywords: Crime, Gender, Social Bond, Vulnerability

Gender roles are the 'social definition' of women and men. They vary among different societies and cultures, classes, ages and during different periods in history. Gender-specific roles and responsibilities are often conditioned by household structure, access to resources, specific impacts of the global economy, and other locally relevant factors such as ecological conditions. As the social order was informally based on the family, individuals were holding a traditional gender role with an unwritten social bond. In traditional Asian societies, women's role as the caretaker at home and in the family and men's role was to provide financial support as the

How to cite this article: Ranaweera K.G.N.U. (2020). The Hidden Factor of Female Offending - Gender. Int. J. Soc. Sci., 9(03): 111-115.

Source of Support: None; Conflict of Interest: None (क) 
breadwinner of the family. Family is the primary and initial social institution in society. As the individual socialization based on the family, concern towards the family should be vital. One's personality and the routine activities are created due to the exposure to the family. Creation of a good person is the social duty of a family, and the gender role plays the prior place towards it.

Traditional gender roles were affected by social change. Moreover, the responsibilities connected with gender roles became more complicated, and each gender roles were adopted different duties according to the responsibilities to be fulfilled. Traditional female gender role was based on the child socialization as today. However, the nature of socialization has been changed to institutionalized education and money based nongovernmental bodies, and the gender role connected with the responsibility also changed. Women had to engage in different professions to earn money on behalf of modernized child socialization. Meanwhile, they had to play the usual gender roles related to biological sex and sex-based vulnerability as well as its advantages. Females could not deny the accouchement; also, the rates of sexual assault against females are always high. This paper emphasizes the impact of gender role on female offending.

\section{Methodology}

A simple random sample of 60 convicted female prisoners from Welikada prison, Sri Lanka were selected as the sample and data were gathered using semistructured interviews. Questions were focused on the crime committed; direct reason for committing, civil status and socio-economic background of the offenders. Data were analyzed using qualitative methodologies.

\section{RESULTS AND DISCUSSION}

The data collected through semi-structured interviews were analyzed using qualitative and quantitative methodologies. Statistical package for the social sciences (SPSS) is progressive software utilized by investigating researchers which offer the assistance they handle necessary information in straightforward steps. SPSS software was used for quantitative analysis, while qualitative methodologies were using for criminological and sociological explanations.

As The chi-square test of homogeneity tests to see whether different columns (or rows) of data in a table come from the same population or not, it was used to identify the different types of crime committed by the offenders in the sample.

\section{Ho - All female offenders committed the same crime}

H1 - All female offenders did not commit the same crime

Table 1: Homogeneity Chi-Square Testing

\begin{tabular}{llll}
\hline $\mathbf{n}$ & Critical Value & Cal Value & $\boldsymbol{\alpha}$ level \\
\hline 60 & 14.9 & 30.17 & 0.05 \\
\hline
\end{tabular}

Source: Field Survey - 2019.

As $\alpha=0.05$, in the level of $0.05, \mathrm{H} 0$ is rejected due to the value of the test statistics is in the critical region. This statistical analysis proved that female offenders had been committed to different types of crimes, with $95 \%$ confidence.

The type of crime, female offenders committed can be recognized via the following pie chart.

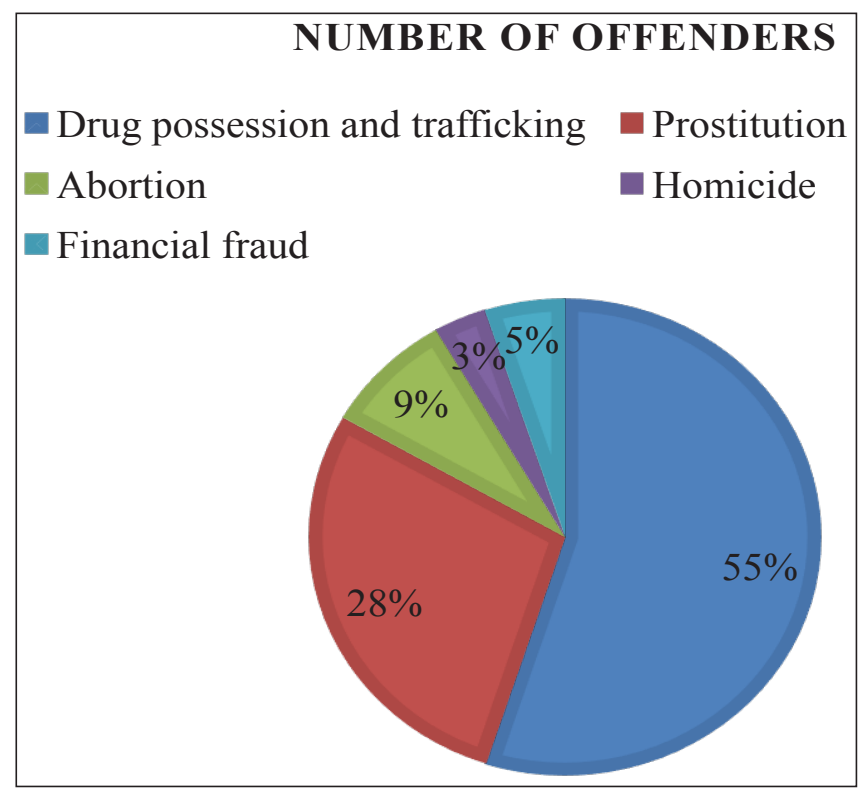

Chart 1: Type of Crime Committed

Source: Field Survey - 2019. 
All 60 offenders could be categorized into five groups based on the "type of crime they committed". Majority of the offenders were accused of "Drug possession and trafficking", and it holds 55\% from the whole. Prostitution $(28 \%)$, abortion $(8.3 \%)$, homicide $(3.3 \%)$ and financial fraud (5\%) were recognized as the crimes committed.

Table 2: Age and the Civil Status of the Offenders

\begin{tabular}{llllll}
\multicolumn{2}{l}{ Civil Status } & & \multicolumn{2}{l}{ Never } \\
Age & Married & $\begin{array}{l}\text { Devarried } \\
\text { Marrived }\end{array}$ & Separated & Total \\
\hline $18-30$ & 20 & 6 & 2 & 1 & 29 \\
$31-60$ & 23 & 5 & 1 & 2 & 31 \\
\hline Total & $\mathbf{4 3}$ & $\mathbf{1 1}$ & $\mathbf{3}$ & $\mathbf{3}$ & $\mathbf{6 0}$ \\
\hline
\end{tabular}

Source: Field Survey - 2019.

Age of the sample was divided into two groups as "1830 " and "31-60", and the same time sample was classified according to the civil status. Majority of the sample belonged to the married category, and the married31-60 aged group was consisted of 23 in number and indicated the highest number.

The Chi-Square Test of Independence determines whether there is an association between categorical variables, to reveal whether there is a relationship between offenders' civil status and age independence chi-square testing was used.

H0 - Civil status and age the female offenders are independent

H1 - Civil status and age the female offenders are dependent

Table 3: Independence chi-square testing

\begin{tabular}{lllll}
\hline $\mathbf{n}$ & $\begin{array}{l}\text { Critical } \\
\text { value }\end{array}$ & $\begin{array}{l}\text { Cal Statistics } \\
\text { value }\end{array}$ & $\alpha$ level & $\begin{array}{l}\text { Coefficient of } \\
\text { contingency }\end{array}$ \\
\hline 60 & 7.812 & 9.785 & 0.05 & 0.721 \\
\hline
\end{tabular}

Source: Field Survey - 2019.

$\alpha=0.05$ level, Cal statistics value (9.785) located in reject region. So, the $\mathrm{HO}$ hypothesis is rejected. This analysis revealed that the Age and the civil status of the female offenders are dependent with $95 \%$ confidence. Moreover, $\mathrm{C}(0.721)$ value indicate a positive relationship between two variables. However, this variable has a strong relationship.

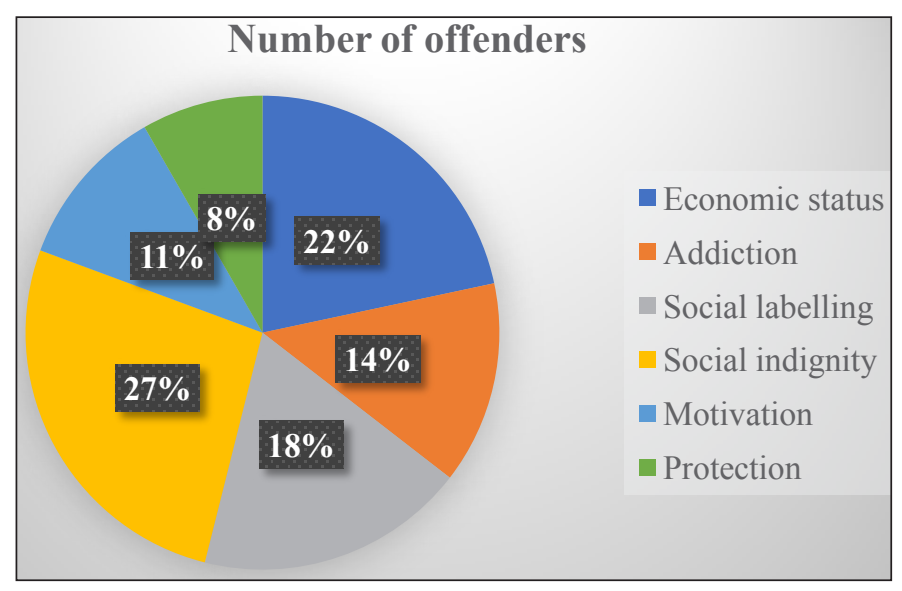

Chart 2: Direct reason for committing the crime

$$
\text { Source: Field Survey - } 2019
$$

Majority of the females have committed crimes due to the social indignity. It indicates $27 \%$ and economic status indicates 22\%. Females committed homicides were revealed the reason for committing the crime as "protection" moreover few drug traffickers had committed the crime as they were threatened. Partner's motivation also has helped some females to drug trafficking and usage.

Regression analysis is a powerful statistical method that allows examining the relationship between two or more variables of interest. The relationship between "Direct reason for committing crime and female offending" was tested using regression analysis.

Table 4: The relationship between the direct reason of committing crime and female offending

\begin{tabular}{lll}
\hline $\begin{array}{l}\text { The direct reason for } \\
\text { committing the crime }\end{array}$ & $\begin{array}{l}\text { Regression } \\
\text { Coefficient }\end{array}$ & Relationship \\
\hline Economic status & 0.772 & Very Strong \\
Addiction & 0.523 & Strong \\
Social labelling & 0.418 & Strong \\
Social indignity & 0.812 & Very Strong \\
Motivation & 0.336 & Week \\
Protection & 0.221 & Week \\
\hline
\end{tabular}

Source: Field Survey - 2019. 
Above analysis elucidate a strong positive relationship between "social indignity and female Criminality, and it indicates 0.812 value of regression coefficient, which baresa very strong relationship. Economic status and Female Criminality denote very strong relationship; 0.772 of regression coefficient value. Social labelling indicates 0.418 regression coefficient value which has created a strong relationship while addiction creates a strong relationship valued 0.532 regression coefficient. Motivation and protection emphasize week relationships with female offending, which indicate regression coefficient values of 0.336 and 0.221 .

A regression analysis was used to examine the relationship between Socio-economic background and female offending.

Table 5: The relationship between socio-economic background and female offending

\begin{tabular}{lll}
\hline Socio-economic background & $\begin{array}{l}\text { Regression } \\
\text { Coefficient }\end{array}$ & Relationship \\
\hline Monthly Income & 0.724 & Strong \\
Number of Children & 0.871 & Very strong \\
Age of the Children & 0.701 & Strong \\
Education Level & 0.369 & Week \\
Occupation & 0.815 & Very strong \\
\hline
\end{tabular}

Source: Field Survey - 2019.

A very strong relationship can be seen between the number of children and female offending; its regression coefficient value is 0.871 . Moreover, the relationship between the Occupation and the female offending is very strong as it indicates 0.815 regression coefficient value. Monthly income and Age of the children indicate a strong relationship with female offending which evaluated the $v$ regression coefficient values of 0.742 and 0.701 while education level of the offender presents week relationship to female offending, which bares regression coefficient 0.369 valued.

\section{CONCLUSION}

"Gender role" has been played a special part in female offender's life which is hidden from direct reasons. Female gender role is created an early civilization based on the household and socialization of children. However, with the intangible change of society has disorganized the female gender role. Male gender role existed with the dominance of the household with minimal change. Female gender role became complicated within the limitations of traditional duties. Children socialization upgraded to structured education alone with money based basic needs. Females entered to all professionals expanding duties hold while maintaining the responsibilities of traditional gender role. Although it showed an increment of education of females, it has supported to "fraud" indirectly. As the primary duties of the female gender role created with biological features of the female body like accouchement, female body base hiding and escaping methods, vulnerability as rape and social labelling of indignity were unchanged. Abortion is a female crime attached to the social indignity in the Sri Lankan context. From the sample, 8.3 percent of females were committed abortions from illegal clinics due to unexpected pregnancies. Two of them were married women, and they wanted to have a considerable age gap between the children due to socio-economic status. The number of unmarried offenders, committed abortions was 3. Females were expected to play a gender role with respect by society, and indirectly unmarried pregnancies were considered as an indignity to the family. Although the mother is the real owner of the fetus after conceiving fetus is also identified as a human being. Although two parties were engaged to create a fetus, the only female is to be charged for abortion. Prostitution is a similar crime for abortion.

Among female offenders, $28 \%$ were committed to prostitution. Ten of them were legally married and engaging in prostitution for money. They all have schooling teenagers, and 3 of offender's children were studying in International schools in Colombo. Homicide offenders were 2 in number. One of them murdered her own husband for self-defence and the other for the house owner. Drug possession and trafficking were based on money and addiction. The number of 55 females were charged under this category, and heroine addicted females were 50 . Other 5 were drug traffickers, and they only committed it for money. Thus economic status, addiction, social labelling, social indignity, motivation 
and protection were identified as primary reasons for offending while the "gender role" bares the root.

Gender roles are still traditional inside with modernized mask on the face. Especially females have to cover up their responsibilities with the gender role in different aspects as the responsibilities have been complicated with social change. Drug-related offences were committed due to addiction and money. Addiction is due to the generosity and consumption of husbands. Money for the households and duties of gender roles are to be fulfilled. Labelling by society is also dealt with the female offending. Society itself has marked the limitations for females by gender role a labelling system of indignity. Prostitution, abortions are the major offences created due to that. Three females have committed financial fraud with fake passport agencies. Entering the money earning battle with Gender-related responsibilities is the reason for that. The research revealed the impact of disorganized gender role and responsibilities of the females had led them to the offending. To neutralize female offending, the gender role should be flexible; responsibilities should be taken by the family as an institution while mutual accountabilities transfer for individuals. Female offending is a normal response by normal females towards abnormal gender conditions of the society.

\section{REFERENCES}

Gender Identity \& Roles I Feminine Traits $\mathcal{E}$ Stereotypes. Plannedparenthood.org. 2020. Retrieved 4 October 2020, from https://www.plannedparenthood.org/learn/gender-identity/ sex-gender-identity/what-are-gender-roles-and-stereotypes.

Gender and Crime in Historical Perspective 2009. 6(1): 147-148. https://doi.org/10.4000/chs.661

Ranaweera, K.G.N.U. 2020. Evolution of the criminological theory: A short overview. Educationjournal.in. Retrieved 1 October 2020, from http://www.educationjournal.in/archives/2020/vol5/ issue $4 / 5-4-16$.

Relations Between Gender and Crime. Lawteacher.net. 2020. Retrieved 7 October 2020, from https://www.lawteacher.net/ free-law-essays/criminology/relations-between-gender-andcrime.php.

Steffensmeier, D. and Allan, E. 1996. Gender and Crime: Toward a Gendered Theory of Female Offending. Annual Review of Sociology, 22(1): 459-487. 
